\title{
Fabrication of Highly Microporous Structure Activated Carbon via Surface Modification with Sodium Hydroxide
}

\author{
Mohd Sahfani Hafizuddin ${ }^{1}$, Chuan Li Lee ${ }^{1, *}$, Kit Ling Chin ${ }^{1}$, Paik San H'ng ${ }^{1,2, *}$, Pui San Khoo ${ }^{1}$ and \\ Umer Rashid ${ }^{3}$ (D) \\ 1 Institute of Tropical Forestry and Forest Products, Universiti Putra Malaysia, Serdang 43400, Malaysia; \\ hafizsahfani@gmail.com (M.S.H.); kitling.chin419@gmail.com (K.L.C.); sansan_0928@hotmail.com (P.S.K.) \\ 2 Faculty of Forestry and Environment, Universiti Putra Malaysia, Serdang 43400, Malaysia \\ 3 Institute of Nanoscience and Nanotechnology (ION2), Universiti Putra Malaysia, Serdang 43400, Malaysia; \\ umer.rashid@yahoo.com \\ * Correspondence: chuanli@upm.edu.my (C.L.L.); ngpaiksan@gmail.com (P.S.H.)
}

Citation: Hafizuddin, M.S.; Lee, C.L.; Chin, K.L.; H'ng, P.S.; Khoo, P.S.; Rashid, U. Fabrication of Highly Microporous Structure Activated Carbon via Surface Modification with Sodium Hydroxide. Polymers 2021, 13 3954. https://doi.org/10.3390/ polym13223954

Academic Editor: Daniela Suteu

Received: 30 August 2021

Accepted: 25 September 2021

Published: 16 November 2021

Publisher's Note: MDPI stays neutral with regard to jurisdictional claims in published maps and institutional affiliations.

Copyright: (c) 2021 by the authors. Licensee MDPI, Basel, Switzerland. This article is an open access article distributed under the terms and conditions of the Creative Commons Attribution (CC BY) license (https:// creativecommons.org/licenses/by/ $4.0 /)$.
Abstract: The aim of this study was to select the optimal conditions for the carbonization process followed by surface modification treatment with sodium hydroxide $(\mathrm{NaOH})$ to obtain a highly microporous activated carbon structure derived from palm kernel shells (PKS) and coconut shells (CS). The effects of the carbonization temperature and $\mathrm{NaOH}$ concentration on the physiochemical properties, adsorption capability, specific surface area, surface morphology, and surface chemistry of PKS and CS were evaluated in this study. The results show that surface-modified activated carbons presented higher surface area values (CS: $356.87 \mathrm{~m}^{2} \mathrm{~g}^{-1}$, PKS: $427.64 \mathrm{~m}^{2} \mathrm{~g}^{-1}$ ), smaller pore size (CS: $2.24 \mathrm{~nm}$, PKS: $1.99 \mathrm{~nm}$ ), and larger pore volume (CS: $0.34 \mathrm{~cm}^{3} \mathrm{~g}^{-1}, \mathrm{PKS}: 0.30 \mathrm{~cm}^{3} \mathrm{~g}^{-1}$ ) than the untreated activated carbon, demonstrating that the $\mathrm{NaOH}$ surface modification was efficient enough to improve the surface characteristics of the activated carbon. Moreover, surface modification via $25 \%$ $\mathrm{NaOH}$ greatly increases the active functional group of activated carbon, thereby directly increasing the adsorption capability of activated carbon (CS: $527.44 \mathrm{mg} \mathrm{g}^{-1}$, PKS: $627.03 \mathrm{mg} \mathrm{g}^{-1}$ ). By applying the $\mathrm{NaOH}$ post-treatment as the ultimate surface modification technique to the activated carbon derived from PKS and CS, a highly microporous structure was produced.

Keywords: concentration; coconut shell; palm kernel shell; surface area; adsorption; post-treatment

\section{Introduction}

Malaysia is a country that is blessed with an abundance of water sources. However, $53 \%$ of the river water in Malaysia is classified as slightly polluted or polluted. River water pollution has recently become a serious problem and adversely affects the sustainability of water resources in the country. High levels of river water pollution have occurred in the states with large numbers of industrial zones and factories, including Selangor, Johor, Penang, and Perak. Industrial areas, sewage, agricultural activities, and animal husbandry activities are the three most common anthropogenic activities that cause river water contamination [1]. Thus, the issue of water treatment research is a critical priority because it has a direct impact on people's lives, social development, and ecological health (i.e., natural, biological, and environmental) [2].

Chemical treatment is among the government's efforts to overcome the issue of river water pollution $[3,4]$. Still, natural organic matter is hard to remove through chemical treatment [5]. Another efficient method for water treatment is the adsorption method, which is one of the most frequently considered treatments to be used in combination with chemical treatment to achieve the highest possible removal efficiencies of natural organic matter and enhance water treatment performance. Activated carbon (a universal adsorbent) is normally used in this adsorption method. With its large surface area and high adsorption capacity, activated carbon is commonly used to remove emerging contaminants from 
water and wastewater [6]. Dyes, heavy metals, petroleum hydrocarbons, pharmaceuticals, pesticides, and other organic matter can be absorbed by activated carbon [7]. However, due to fluctuating prices and the sustainability issues of coal, the widespread use of activated carbon is sometimes restricted [8]. Recently, considerable attention has been given to biomass conversion as a platform to economically produce activated carbon from biorenewable resources with quality that is comparable to coal-based activated carbon [9]. Hence, the conversion of biomass into activated carbon can provide an alternative way to reduce the carbon emissions, reuse waste materials, and contribute significantly to mitigating climate change [10]. Among the different types of biomass, the high density and rigidity of nutshell biomass such as coconut shells (CS) and palm kernel shells (PKS) make for a promising, modifiable material for highly microporous activated carbon production. Additionally, both of these lignocellulosic biomass are still underutilized in Malaysia. Thus, CS and PKS have the aptitude for use as inexpensive adsorbents, as they are not only an underused resource are easily available and are a sustainable resource [11].

Generally, biomass materials have inherent limits and have low adsorption capacity without additional treatment $[12,13]$. To surmount these limitations, processes such as amination, sulfonation, surface oxidation, and pore structure modifcation can provide new insights into the preparation of high-adsorption adsorbent materials [14]. Moreover, the development of micropores leads to the creation of high-surface areas [15]. Thus, in the present study, an attempt has been made to produce highly microporous activated carbon derived from CS and PKS to enhance their adsorption capacity via surface modification with sodium hydroxide $(\mathrm{NaOH})$. $\mathrm{NaOH}$ presents three advantages in terms of lower weight dosage, lower cost, and the least amount corrosion compared to $\mathrm{KOH}$. Furthermore, the byproducts produced from $\mathrm{NaOH}$ activation, such as $\mathrm{Na}_{2} \mathrm{CO}_{3}$ and $\mathrm{Na}_{2} \mathrm{SiO}_{3}$, are non-toxic and non-hazardous. Both by-products $\left(\mathrm{Na}_{2} \mathrm{CO}_{3}\right.$ and $\mathrm{Na}_{2} \mathrm{SiO}_{3}$ without any other contaminant) could be reused as raw materials after the filtration process [16]. Henceforth, a surface modification process using $\mathrm{NaOH}$ could be regarded as clean and green technology.

The overall objective of this work is to investigate the effects of $\mathrm{NaOH}$ surface modification (concentration of $\mathrm{NaOH}$ ) on the physiochemical and surface characteristics of activated carbons derived from CS and PKS. The main limitations to the adsorption capacity that are extremely difficult to control in commercial carbons are poor pore size characteristics and surface properties [15]. Carbonization processes play a significant role in the development of the initial pore structure. The initial pores that are created during the carbonization process is an important basic feature of activated carbon that has a major influence on the following $\mathrm{NaOH}$ post-treatment effects on the characteristics of the final structure of the activated carbon. Thus, the aim of this study was to discover the ideal fabrication conditions for the carbonization process followed by $\mathrm{NaOH}$ post-treatment to obtain a highly microporous activated carbon structure derived from palm kernel shells (PKS) and coconut shells (CS). The relationships between the surface structure and the pore assessment were also evaluated. In order to study the effect of micropore characteristics on the surface area of the activated carbon, the data were analysed to examine the correlation between the micropore surface area and the total surface area.

\section{Materials and Methods}

\subsection{Fabrication of Activated Carbon}

CS was collected from Pasar Besar Kuantan, Pahang, and PKS was collected from Seri Ulu Langat Palm Oil Mill, Dengkil Selangor. Both types of nutshells were cleaned and dried in an oven at $105^{\circ} \mathrm{C}$ for $48 \mathrm{~h}$. The dried nutshells were then crushed and sieved to a 2-5 $\mathrm{mm}$ size range.

A specified mass of the dried nutshells were impregnated with $30 \%$ phosphoric acid $\left(\mathrm{H}_{3} \mathrm{PO}_{4}\right)$ with an impregnation mass ratio of $1: 1$ at $80{ }^{\circ} \mathrm{C}$ for $2 \mathrm{~h}$. The pretreated particles were filtered and washed with distilled water. The washed $\mathrm{H}_{3} \mathrm{PO}_{4}$ pretreated particles were then dried at $105^{\circ} \mathrm{C}$ for $48 \mathrm{~h}$ prior to the carbonization process. The dried pretreated samples were then placed in the muffle furnace to undergo the carbonization process with 
relative temperatures of 500,600 , and $700{ }^{\circ} \mathrm{C}$ for $75 \mathrm{~min}$. The activated carbons were kept in desiccators for further evaluation.

\subsection{Surface Modification with $\mathrm{NaOH}$}

The specified mass of the activated carbon was soaked with $\mathrm{NaOH}$ (impregnation ratio of 1:1) with four different concentrations $(6.25,12.5,25$, and 50\%) for $24 \mathrm{~h}$. Finally, all of the obtained activated carbons were thoroughly washed with distilled water until they attained a pH of 6 to 7 . The washed samples were dried at $105^{\circ} \mathrm{C}$ for $48 \mathrm{~h}$ and were then stored in desiccators.

\subsection{Evaluation}

The characteristics of the activated carbon, including mass yield, ash content, methylene blue adsorption, iodine blue adsorption, BET surface areas, and surface characteristics were determined as previously described $[10,13,14]$.

\subsubsection{Mass Yield}

The activated carbon yield was calculated as below

$$
\text { Yield }(\%)=\frac{\text { Dry weight of final activated carbon }(\mathrm{g})}{\text { Dry weight of raw material }(\mathrm{g})} \times 100
$$

\subsubsection{Ash Content}

The TAPPI standard method, T211 om-85, was used to determine the ash content. The oven-dried sample ( $2 \mathrm{~g}$ ) was burnt (dry oxidation) in a muffle furnace model at $575 \pm 25^{\circ} \mathrm{C}$ for $4 \mathrm{~h}$. This standard test method was used to determine the volume of ash remaining after the dry oxidation of the sample. The ash percentage was calculated by:

$$
\text { Ash }(\%)=\frac{\text { Weight of solids remaining }(\mathrm{g})}{\text { Original weight of carbon }(\mathrm{g})} \times 100
$$

\subsubsection{Methylene Blue Adsorption}

The methylene blue number is defined as the milligrams of methylene blue or maximum amount of dye adsorbed on $1.0 \mathrm{~g}$ of adsorbent. The methylene blue number was determined according to the standard method (JIS K 1470-1991). In this assay, $0.05 \mathrm{~g}$ of adsorbent were placed in contact with $50 \mathrm{~mL}$ of a methylene blue solution at different concentrations $\left(10,25,50,100,250,500\right.$, and $\left.1000 \mathrm{mgL}^{-1}\right)$ for $24 \mathrm{~h}$ at room temperature (of $25^{\circ} \mathrm{C} \pm 2{ }^{\circ} \mathrm{C}$ ). After shaking for $24 \mathrm{~h}$, the suspensions were filtered, and the remaining concentration of methylene blue in the solution was determined spectrophotometrically at a $\lambda$ max of $660 \mathrm{~nm}$ using an UV/Vis spectrophotometer (UV- CECIL- CE-100). Standard methylene blue solutions were used for calibration. The amount of methylene blue adsorbed from each solution was calculated as below:

$$
\text { Methylene blue adsorption }(\mathrm{mg} / \mathrm{g})=\frac{[(\mathrm{C} 0-\mathrm{Ce}) \times \mathrm{V}](\mathrm{mg})}{\mathrm{M}(\mathrm{g})} \times 100
$$

where:

$\mathrm{C} 0\left(\mathrm{mg} \mathrm{L}^{-1}\right)=$ the concentration of the methylene blue solution at starting time $(\mathrm{t}=0)$;

$\mathrm{Ce}\left(\mathrm{mg} \mathrm{L}^{-1}\right)=$ the concentration of the methylene blue solution at equilibrium time;

$\mathrm{V}(\mathrm{L})=$ the volume of the solution treated;

$\mathrm{M}(\mathrm{g})=$ the mass of the adsorbent.

\subsubsection{Iodine Adsorption Number}

The ASTM D4607-94 method was used to determine the iodine adsorption number for the carbons. The iodine adsorption number can be explained as the milligrams of iodine adsorbed by $1.0 \mathrm{~g}$ of carbon. A conical flask with $10 \mathrm{~mL}$ of $5 \% \mathrm{HCl}$ and $1.0 \mathrm{~g}$ of activated 
carbon was swirled until all of the activated carbon was wetted. The wetted activated carbon was boiled for exactly $30 \mathrm{~s}$, and the solution was cooled to room temperature. An amount of $100 \mathrm{~mL}$ of $0.1 \mathrm{~N}\left(0.1 \mathrm{Mol} \mathrm{L}^{-1}\right)$ iodine solution was then added to the mixture in the conical flask. The mixture was later filtered using a Whatman $2 \mathrm{~V}$ filter paper. Finally, $50 \mathrm{~mL}$ of this filtrate was titrated with $0.1 \mathrm{~N}\left(0.1 \mathrm{Mol} \mathrm{L}^{-1}\right)$ sodium thiosulphate in the presence of starch as indicator. The amount of iodine adsorbed per gram of carbon was calculated as shown in Equation (4):

Iodine adsorption, $(\mathrm{mg} / \mathrm{g})=\left(\left\{\left(\mathrm{N}_{1} \times 126.93 \times \mathrm{N}_{2}\right)-\left[\left(\mathrm{S}_{1}+\mathrm{H}_{1}\right) / \mathrm{F}_{1}\right] \times\left(\mathrm{S}_{1} \times 126.93\right) \times \mathrm{S}_{2}\right\}\right) / \mathrm{M}$

where:

$\mathrm{N}_{1}$ = Iodine solution normality;

$\mathrm{N}_{2}=$ Added volume of iodine solution;

$\mathrm{H}_{1}=$ Added volume of $5 \% \mathrm{HCI}, \mathrm{ml}$;

$\mathrm{F}_{1}=$ Filtrate volume used in titration, $\mathrm{ml}$;

$\mathrm{S}_{1}=$ Sodium thiosulfate solution normality;

$\mathrm{S}_{2}=$ Consumed volume of sodium thiosulfate solution, $\mathrm{ml}$;

$\mathrm{M}=$ Mass of carbon, $\mathrm{g}$.

\subsubsection{Surface Characteristic}

The BET surface areas were determined by nitrogen adsorption at $77 \mathrm{~K}$. Once the carbon was being degassed at $300{ }^{\circ} \mathrm{C}$ in an inert condition for $24 \mathrm{~h}$, the nitrogen gas adsorption measurements were completed. A relative pressure of between 10.5 and 0.995 of nitrogen gas was used to obtain the $\mathrm{N}_{2}$ adsorption isotherm. Porosity is defined as the ratio of the total pore volume to the volume of the particle or agglomerate. In the context of physisorption, it is expedient to classify pores according to their size (IUPAC recommendation).

\subsubsection{Surface Morphology}

The surface characteristics of a material refer to the properties associated with its surface. Typically, measurements of surface area, surface roughness, pore size, and reflectivity constitute surface characteristics. To obtain the micrographs of the prepared activated carbon, a scanning electron microscope was used. Scanning electron microscopy (SEM) analysis was conducted under optimum conditions to analyse the surface texture and the development of porosity in the activated carbon. In the SEM analysis, a small quantity of the dried samples was placed in the sample container of a scanning electron microscope and was sputtered with gold and palladium to acquire sufficient conductivity.

\subsubsection{FTIR}

The surface functional groups of the samples were analysed using a Fourier transform infrared spectroscope (FTIR- Perkin Elmer Spectrum 100-IR, Tokyo, Japan). The dry samples were crushed into powder form and were inserted into the FTIR chamber. The spectra were recorded at a resoltion from 4000 to $700 \mathrm{~cm}^{-1}$ in the mid-infrared region.

\subsection{Statistical Analysis}

Statistical analyses were conducted using the statistical package SPSS for Windows, version 16.0 (SPSS, Chicago, IL, USA), which was used to evaluate the adsorption property data of the activated carbons for analysis of variance (ANOVA) at a $95 \%$ confident level $(p \leq 0.05)$. The Tukey-Kramer multiple comparisons test was applied to analyse the differences between the treatment effects when significance was observed. The effects were considered to be not statistically significant when the $p$-value was higher than 0.05 at the $95 \%$ confidence level. In this research, the Pearson correlation was used to develop a correlation between the proportion of the micropores and the specific surface area. 


\section{Results and Discussion}

\subsection{Physiochemical Properties of the Activated Carbon}

The physiochemical properties of the activated carbon without $\mathrm{NaOH}$ surface modification (as shown in Table 1) were used as the reference samples in this study. According to the analysis of variance (ANOVA), the combination effects of the carbonization temperature and $\mathrm{NaOH}$ post-treatment concentration on the mass yield and ash content were highly significant $(p<0.01)$. The average values that were significant were compared using Tukey's test and are summarized in Table 2.

Table 1. Physiochemical properties of activated carbon without $\mathrm{NaOH}$ surface modification.

\begin{tabular}{cccccccccc}
\hline $\begin{array}{c}\text { Carbonization } \\
\text { Temperature }\left({ }^{\circ} \mathbf{C}\right)\end{array}$ & \multicolumn{2}{c}{ Mass Yield (\%) } & \multicolumn{2}{c}{ Ash Content (\%) } & \multicolumn{2}{c}{ Methylene Blue (mg/g) } & \multicolumn{2}{c}{ Iodine Adsorption (mg/g) } \\
\cline { 2 - 9 } & CS & PKS & CS & PKS & CS & PKS & CS & PKS \\
\hline 500 & 36.23 & 37.08 & 24.34 & 24.23 & 86.128 & 115.350 & 308.693 & 305.901 \\
600 & 26.93 & 27.04 & 35.51 & 34.39 & 264.792 & 212.757 & 406.430 & 372.920 \\
700 & 27.44 & 27.26 & 35.50 & 31.08 & 280.429 & 212.757 & 441.800 & 402.710 \\
\hline
\end{tabular}

Table 2. ANOVA for the mass yield and ash content of activated carbon.

\begin{tabular}{|c|c|c|c|c|c|}
\hline \multirow{2}{*}{$\begin{array}{l}\text { Carbonization } \\
\text { Temperature }\left({ }^{\circ} \mathrm{C}\right)\end{array}$} & \multirow{2}{*}{$\begin{array}{c}\mathrm{NaOH} \\
\text { Concentration (\%) }\end{array}$} & \multicolumn{2}{|c|}{ Mass Yield (\%) } & \multicolumn{2}{|c|}{ Ash Content (\%) } \\
\hline & & CS & PKS & CS & PKS \\
\hline 500 & 6.25 & $36.19^{a}$ & $36.84^{a}$ & $24.16^{\mathrm{a}}$ & $24.10^{\mathrm{a}}$ \\
\hline 500 & 12.5 & $35.42^{b}$ & $35.54^{b}$ & $25.31^{b}$ & $25.30^{b}$ \\
\hline 500 & 25 & $33.75^{e}$ & $33.92^{d}$ & $27.01^{d}$ & $26.72^{d}$ \\
\hline 500 & 50 & $32.82^{f}$ & $33.39^{\mathrm{e}}$ & $27.20^{\mathrm{e}}$ & $27.30^{\mathrm{f}}$ \\
\hline 600 & 6.25 & $35.31^{c}$ & $34.84^{c}$ & $26.30^{c}$ & $25.25^{b}$ \\
\hline 600 & 12.5 & $34.53^{b}$ & $33.93^{d}$ & $27.01^{d}$ & $27.09^{\mathrm{e}}$ \\
\hline 600 & 25 & $28.12^{i}$ & $33.11^{\mathrm{f}}$ & $29.51 \mathrm{~g}$ & $28.12 \mathrm{~g}$ \\
\hline 600 & 50 & $27.63^{j}$ & $32.08^{g}$ & $31.10^{\mathrm{i}}$ & $28.90^{\mathrm{h}}$ \\
\hline 700 & 6.25 & $30.91 \mathrm{~g}$ & 33.2 ef & $26.30^{c}$ & $26.01^{c}$ \\
\hline 700 & 12.5 & $29.96^{\mathrm{h}}$ & $31.08^{h}$ & $28.38^{f}$ & $29.50^{\mathrm{i}}$ \\
\hline 700 & 25 & $27.36^{k}$ & $29.65^{i}$ & $30.81^{h}$ & $31.16^{j}$ \\
\hline 700 & 50 & $27.02^{1}$ & $28.20^{j}$ & $32.01^{j}$ & $32.49^{k}$ \\
\hline \multicolumn{2}{|c|}{$p$-value } & $<0.001$ & $<0.001$ & $<0.001$ & $<0.001$ \\
\hline
\end{tabular}

Note: Means followed by the same letter in the same column are not significantly different at $p \leq 0.05$ according to Tukey's multiple comparisons test.

Table 1 illustrates carbonization treatments for the CS and PKS at temperatures ranging from 500 to $700{ }^{\circ} \mathrm{C}$. For both of the reference activated carbons, the mass yield decreases significantly while the ash content increases as the carbonization temperature increases. Table 2 presents the yield of the activated carbon obtained from the combination effects of the carbonization temperature and the $\mathrm{NaOH}$ post-treatment concentrations. As stated by $\mathrm{Xu}$ et al. [17], to balance the porosity and density of carbon, the carbonization temperature must be optimized. It was discovered that the yield of the activated carbons that were produced were inversely proportional to the carbonization temperature, with a lower yield obtained at higher carbonization temperatures. This could be due to the release of more volatile matter when carbon is activated at a higher temperature [18]. A lower activated carbon yield was obtained due to the release of a higher amount of volatile matter from the char [19]. A large number of gaseous components, including the surface oxygen $(\mathrm{O})$-containing groups, and contents of hydrogen $(\mathrm{H}), \mathrm{N}$, and $\mathrm{O}$ were greatly reduced when the temperature was raised from $500{ }^{\circ} \mathrm{C}$ to $900{ }^{\circ} \mathrm{C}[20,21]$. The effects of the $\mathrm{NaOH}$ concentration on the activated carbon mass yield are shown in Table 2. An activated carbon mass yield of up to $36 \%$ was obtained from the PKS and CS carbonization via the approach including the addition of $\mathrm{NaOH}$. From Table 2, it is evident that the mass yield increased by 
$11 \%$ and $17 \%$ when there were surface modifications using a $\mathrm{NaOH}$ concentration of $6.25 \%$ for CS and PKS activated carbon, respectively. A further increase in the concentration of $\mathrm{NaOH}$ resulted in a steady reduction in the mass yield. This indicates that the application of a solution with a greater number of alkali metal hydroxides facilitated the removal of more volatile components from the char during the subsequent surface modification process. In addition, more alkaline hydroxide molecules were used to break chemical bonds such as alkyl-aryl bonding within the char matrix when higher chemical concentrations were used [19]. In addition, $\mathrm{NaOH}$ provided an elimination and dehydration reaction, breaking the $\mathrm{C}-\mathrm{O}-\mathrm{C}$ and $\mathrm{C}-\mathrm{C}$ bonds of the raw material, also justifying a decline in carbon yield [22].

High ash content in agricultural biomass such as PKS and CS is one of the main barriers to achieving high-quality activated carbon [15]. The positive effects of the $\mathrm{NaOH}$ surface modifications were counteracted by the amount of ash left on the activated carbon. Table 2 reveals that $\mathrm{NaOH}$ surface modification can potentially lower the ash content in activated carbon to $24 \%$. The alkali used in this process is expected to react the mineral constituents as follows:

$$
\begin{gathered}
2 \mathrm{NaOH}+\mathrm{SiO}_{2} \rightarrow \mathrm{Na}_{2} \mathrm{SiO}_{3}+\mathrm{H}_{2} \mathrm{O} \\
2 \mathrm{NaOH}+\mathrm{AlO}_{2} \mathrm{O}_{3} \rightarrow 2 \mathrm{NaAlO}_{2}+\mathrm{H}_{2} \mathrm{O}
\end{gathered}
$$

As shown in reaction Equations (5) and (6), the removal of the major part of the quartz and alumina is affected by the formation of sodium silicate and aluminate [23]. When the $\mathrm{NaOH}$ concentration increased, the ash content increased. Furthermore, higher concentrations do not appear to be economically feasible for industrial-scale demineralization. Therefore, it was preferable to create a microporous active carbon structure with the lowest concentration of $\mathrm{NaOH}(6.25-25 \%)$ possible. Table 2 shows that the ash content of the activated carbon increased as the carbonization temperature increased. When the temperature was raised from 500 to $700{ }^{\circ} \mathrm{C}$, the ash content in the CS and PKS increased from 24.16 to $26.30 \%$ and 24.10 to $26.01 \%$, respectively. The increase in ash content is caused by the progressive concentration of minerals and the destructive volatilization of lignocellulosic materials as the temperature rises [18].

\subsection{Adsorption Properties of the Activated Carbon}

The adsorption properties of the surface-modified activated carbon derived from CS and PKS are compiled in Table 3. The ANOVA analysis revealed the combination effects of the carbonization temperature and the $\mathrm{NaOH}$ post-treatment concentration on the methylene blue and iodine adsorption properties were highly significant $(p<0.01)$. The average values that were significant were compared using Tukey's test and are summarized in Table 3.

According to Chin et al. [15], methylene blue is used to measure pores greater than $1.5 \mathrm{~nm}$ in diameter. The combination effects of carbonization temperatures and $\mathrm{NaOH}$ posttreatment concentrations on methylene blue adsorption are shown in Table 2. An increase in the adsorption properties was observed with the application of a surface modification technique using $\mathrm{NaOH}$. The lower adsorption rate could be due to a scarcity of active sites on the activated carbon's surface. As the porosity of the adsorbent increases, the number of active sites available for methylene blue adsorption increases [11]. Aside from that, the increasing of the adsorption properties with the increasing of $\mathrm{NaOH}$ concentration could be due to the removal of ash components from the activated carbon. The adsorptive nature of the activated carbon was questioned due to the amount of ash content that was present because it is not only causes an inhibiting effect but also affects the adsorption characteristic of different organic chemicals. However, increasing the concentration of $\mathrm{NaOH}$ to $25 \%$ reduced the adsorption of methylene blue on both types of the activated carbons. The result indicates that the use of high carbonization temperatures accelerates the $\mathrm{NaOH}$ surface modification process. Table 3 depicts how the surface-modified samples from the activated carbon prepared at $700{ }^{\circ} \mathrm{C}$ achieved the highest adsorption capability. 
This may be due to activated carbon prepared with high temperatures and with a low moisture content, which can provide more adsorption sites becoming available for use as an adsorbent. The moisture content in the activated carbon would have blocked the adsorption sites of the activated carbon, thus decreasing its adsorption efficiency [19]. Moreover, thermal treatment resulted in a higher rate of volatile content removal and pore structure development [15].

Table 3. ANOVA for adsorption properties of activated carbon.

\begin{tabular}{|c|c|c|c|c|c|}
\hline \multirow{2}{*}{$\begin{array}{c}\text { Carbonization } \\
\text { Temperature }\left({ }^{\circ} \mathrm{C}\right)\end{array}$} & \multirow{2}{*}{$\begin{array}{c}\mathrm{NaOH} \\
\text { Concentration (\%) }\end{array}$} & \multicolumn{2}{|c|}{ Methylene Blue (mg/g) } & \multicolumn{2}{|c|}{ Iodine Adsorption (mg/g) } \\
\hline & & CS & PKS & CS & PKS \\
\hline 500 & 6.25 & $108.685^{j}$ & $173.025^{j}$ & $327.310^{\mathrm{i}}$ & $314.279^{k}$ \\
\hline 500 & 12.5 & $208.399 \mathrm{~g}$ & $208.912 \mathrm{~g} \mathrm{~h}$ & $336.618^{h}$ & $333.826^{\mathrm{i}}$ \\
\hline 500 & 25 & $187.380^{\mathrm{h}}$ & $192.763 \mathrm{~h} \mathrm{i}$ & $358.958^{\mathrm{j}}$ & $353.373^{h}$ \\
\hline 500 & 50 & $177.126^{\mathrm{i}}$ & $185.842^{\mathrm{h} \mathrm{i}}$ & $309.625^{j}$ & $375.713^{g}$ \\
\hline 600 & 6.25 & $350.408^{d}$ & $302.217^{\mathrm{d}}$ & $307.763^{j}$ & $476.241^{f}$ \\
\hline 600 & 12.5 & $400.905^{\mathrm{a}}$ & $331.952^{c}$ & $414.807^{\mathrm{e}}$ & $504.166^{c}$ \\
\hline 600 & 25 & $395.266^{b}$ & $261.204^{\mathrm{e}}$ & $442.732^{\mathrm{d}}$ & $543.260^{b}$ \\
\hline 600 & 50 & $388.345^{c}$ & $218.909 \mathrm{fg}$ & $361.751 \mathrm{~g}$ & $318.002^{\mathrm{j}}$ \\
\hline 700 & 6.25 & $296.321^{\mathrm{e}}$ & 238.903 ef & $479.965^{c}$ & $487.411^{\mathrm{e}}$ \\
\hline 700 & 12.5 & $226.855^{f}$ & $409.877^{\mathrm{a}}$ & $499.512^{b}$ & $543.260^{b}$ \\
\hline 700 & 25 & $110.480^{j}$ & $376.297^{b}$ & $527.436^{\mathrm{a}}$ & $627.034^{a}$ \\
\hline 700 & 50 & $72.799 \mathrm{k}$ & $257.871^{\mathrm{e}}$ & $401.776^{\mathrm{f}}$ & $495.789^{d}$ \\
\hline \multicolumn{2}{|c|}{$p$-value } & $<0.001$ & $<0.001$ & $<0.001$ & $<0.001$ \\
\hline
\end{tabular}

Note: Means followed by the same letter (a-k) in the same column are not significantly different at $p \leq 0.05$ according to Tukey's multiple comparisons test.

Iodine adsorption is the most fundamental parameter used to define and characterize the performance of an adsorbent [24]. The iodine value can indicate the total surface area and micropore volume of activated carbon [11]. According to Chin et al. [15], the discovery of new methods for controlling porosity and microarchitecture has the potential to lead to the refinement of lignocellulose carbon resources as advanced functional materials. Thus, $\mathrm{NaOH}$ surface modification has a high potential to produce a highly microporous activated carbon structure that can be used to remove a variety of pollutants from wastewater effluent. When CS activated carbon was modified with $25 \% \mathrm{NaOH}$, it exhibited the highest iodine adsorption. The increased iodine adsorption capacity is a result of the high degree of activation. Activated carbon prepared via $50 \% \mathrm{NaOH}$ had the lowest iodine adsorption. The micropores might undergo coalescence as a result of deeper carbon decomposition where there is a higher $\mathrm{NaOH}$ concentration.

Table 1 illustrates that the carbonization temperature is critical in the pre-formation of pores (reference activated carbon) in order to produce highly microstructured activated carbon. This could be due to the fact that some volatile compounds can only be removed at higher carbonization temperatures $\left(>650{ }^{\circ} \mathrm{C}\right)$ [18]. Higher volatile compounds in the reference sample may "block" pore spaces, resulting in a smaller surface area. Simultaneously, increasing the carbonization temperature from $500{ }^{\circ} \mathrm{C}$ to $700{ }^{\circ} \mathrm{C}$ prior to surface modification treatment resulted in an increased of iodine adsorption for the surface-modified samples. This may be attributable to the reaction of $\mathrm{NaOH}$ and the development of new pores in the carbon structure [25]. The chemical reactions of $\mathrm{NaOH}$ and carbon during the surface modification process can be written as follows [26]:

$$
\begin{gathered}
4 \mathrm{NaOH}+\mathrm{C} \rightarrow \mathrm{Na}_{2} \mathrm{CO}_{3}+\mathrm{Na}_{2} \mathrm{O}+2 \mathrm{H}_{2} \\
2 \mathrm{Na}_{2} \mathrm{O}+\mathrm{C} \rightarrow 4 \mathrm{Na}+\mathrm{CO}_{2} \\
\mathrm{Na}_{2} \mathrm{CO}_{3}+2 \mathrm{C} \rightarrow 2 \mathrm{Na}+3 \mathrm{CO}
\end{gathered}
$$


Based on these findings, it was ascertained that the pre-formation of porous entities on the surface structure of the activated carbon facilitated the $\mathrm{NaOH}$ surface modification process. Moreover, alkali materials are well known for being able to penetrate swollen cellulose fiber and to increase certain areas of the cell wall, making chemical interactions easier. After alkali treatment, lignin was removed extensively, the mechanical properties of the cell wall were decreased, the cellulose fibrils were collapsed, and the porosity of the surface was increased [27]. This explains how $\mathrm{NaOH}$ surface modification on activated carbon prepared at $700{ }^{\circ} \mathrm{C}$ achieved the highest iodine adsorption.

\subsection{Surface Characteristic of Activated Carbon}

In this study, the reference samples and surface-modified activated carbon with the highest adsorption properties were evaluated on the surface area. This includes referenceactivated carbon samples prepared at $700{ }^{\circ} \mathrm{C}$ for $75 \mathrm{~min}$ and surface-modified activated carbon $\left(700^{\circ} \mathrm{C}, 75 \mathrm{~min}\right)$ post-treated with $25 \% \mathrm{NaOH}$. Figure 1 depicts the total BET surface area and porosity ratio of the prepared activated carbon samples, while Figure 2 illustrates pore measurements (pore size and pore volume) of the samples.

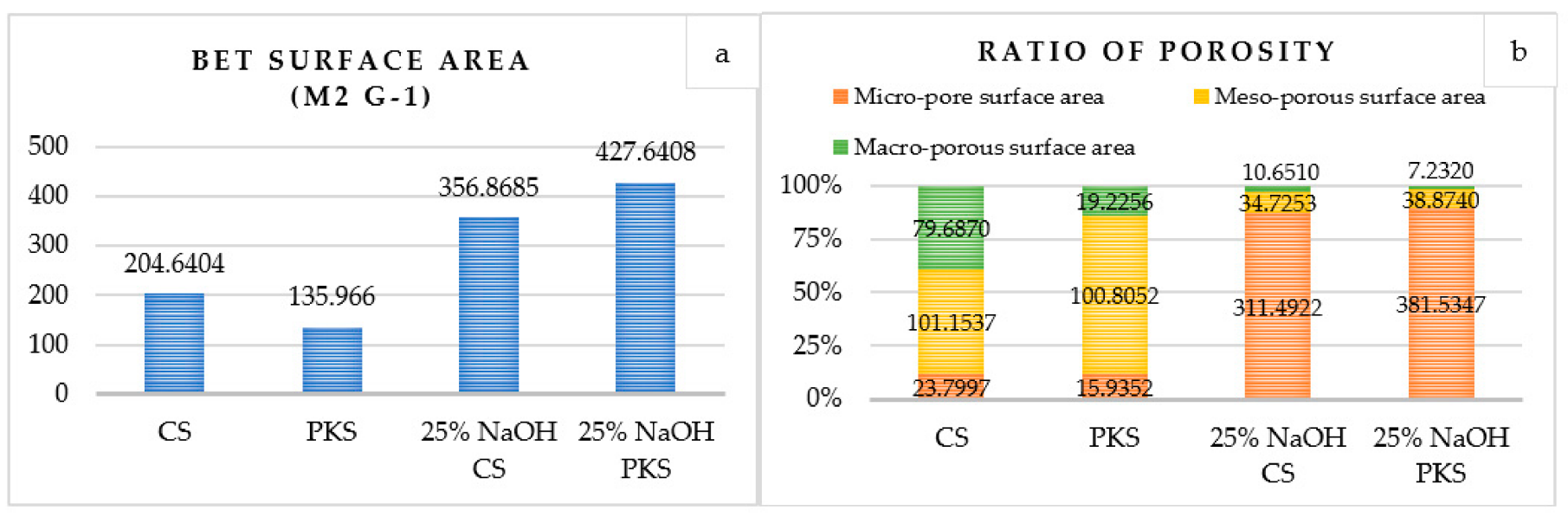

Figure 1. Surface characteristics of activated carbon: (a) BET surface area and (b) porosity ratio for activated carbon prepared at $700{ }^{\circ} \mathrm{C}$ for $75 \mathrm{~min}$ (reference sample) and activated carbon $\left(70{ }^{\circ} \mathrm{C}, 75 \mathrm{~min}\right.$ ) post-treated with $25 \% \mathrm{NaOH}$.

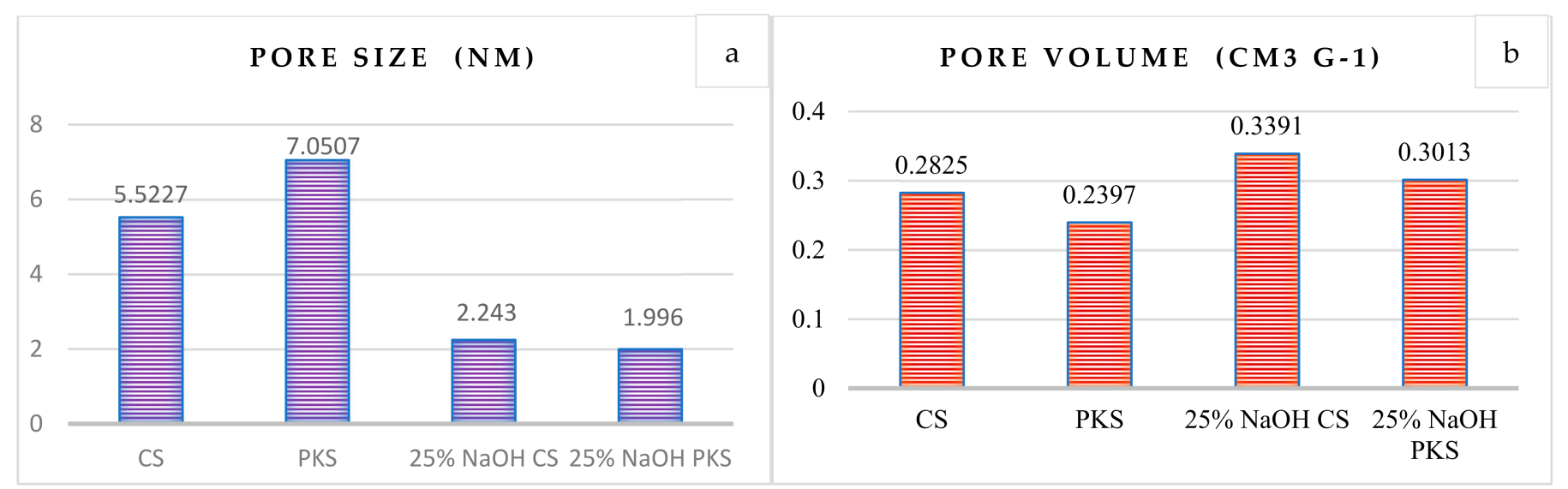

Figure 2. Pore measurements of activated carbon: (a) Pore size and (b) pore volumes for activated carbon prepared at $700{ }^{\circ} \mathrm{C}$ for $75 \mathrm{~min}$ (reference sample) and activated carbon $\left(700^{\circ} \mathrm{C}, 75 \mathrm{~min}\right)$ post-treated with $25 \% \mathrm{NaOH}$.

According to the porosity ratio (Figure $1 \mathrm{~b}$ ), higher $\mathrm{NaOH}$ concentrations facilitate the production of activated carbon micropores. Micropores occupied $80 \%$ of the total pore ratio of the surface-modified activated carbon. Changes in the structure and adsorption 
properties of activated carbon were observed as a result of the surface modifications with $\mathrm{NaOH}$. The following equations outline the proposed reactions during $\mathrm{NaOH}$ activation:

$$
\begin{gathered}
6 \mathrm{NaOH}+2 \mathrm{C} \rightarrow 2 \mathrm{Na}+2 \mathrm{Na}_{2} \mathrm{CO}_{3}+3 \mathrm{H}_{2} \\
\mathrm{Na}_{2} \mathrm{CO}_{3} \rightarrow \mathrm{Na}_{2} \mathrm{O}+\mathrm{CO}_{2} \\
2 \mathrm{Na}+\mathrm{CO}_{2} \rightarrow \mathrm{Na}_{2} \mathrm{O}+\mathrm{CO}
\end{gathered}
$$

The possible reactions between active substances and the surface of the organic precursor resulted in the formation of micropores on the activated carbon surface due to the release of $\mathrm{CO}, \mathrm{CO}_{2}$, and $\mathrm{H}_{2}$ gases (refer to Equations (10)-(12)), which are produced by $\mathrm{Na}_{2} \mathrm{CO}_{3}$ decomposition at high temperatures and during hydroxyl reduction, respectively. Moreover, alkali metal intercalation into the carbon structure may result in the formation of an activated carbon micropore [28]. When the surface of PKS-activated carbon was modified with $25 \% \mathrm{NaOH}$, it achieved the highest surface area $\left(427.64 \mathrm{~m}^{2} / \mathrm{g}\right)$, which was approximately three times greater than the activated carbon prepared without surface modification. This demonstrates that $\mathrm{NaOH}$ is critical for the development of a high surface area for activated carbon. It was also observed that the addition of $\mathrm{NaOH}$ increased the BET surface area but decreased the activated carbon yields. Figure 2 depicts the pore size distributions of the prepared activated carbon. The pore measurement results showed that the addition of $\mathrm{NaOH}$ resulted in a higher surface area for activated carbon by reducing the pore size. For the activated carbons prepared without surface modification using $\mathrm{NaOH}$, the large pore size resulted in the least efficient adsorption properties. Furthermore, the high surface area could be attributed to the larger total pore volume in the surface modified activated carbons (refer Figure 2b).

The $\mathrm{N}_{2}$ adsorption isotherm acquired from the prepared activated carbons is established in Figure 3. Both of the activated carbon reference samples prepared without surface modification conform to a type IV isotherm. Figure 3 signifies that the initial part of the type IV isotherm for carbon represents micropore filling, and the slope of the plateau at high relative pressure is due to multilayer adsorption on non-microporous surfaces, i.e., in mesopores, in the macropores, and on the external surface [29]. This infers that both of the activated carbon reference samples had a mesoporous structure that mostly contained mesopores. The activated carbons with $\mathrm{NaOH}$ surface modification conformed to the type I isotherm, disclosing that the activated carbons are produced by microporous solids with relatively small external surfaces such as activated carbons, molecular sieve zeolites, and certain porous oxides. The steep uptake at a very low $\mathrm{p} / \mathrm{p}^{\circ}$ is due to the enhanced adsorbent-adsorptive interactions in the narrow micropores (micropores of molecular dimensions), resulting in micropore filling at a very low $\mathrm{p} / \mathrm{p}^{\circ}$. The type I isotherm implies the near absence of mesopores and macropores inside of the material [11]. The results show that the $\mathrm{N}_{2}$ adsorption isotherm for activated carbon correlates with the pore measurement results. For activated carbon with $\mathrm{NaOH}$ surface modification, the presence of micropores is advantageous. 


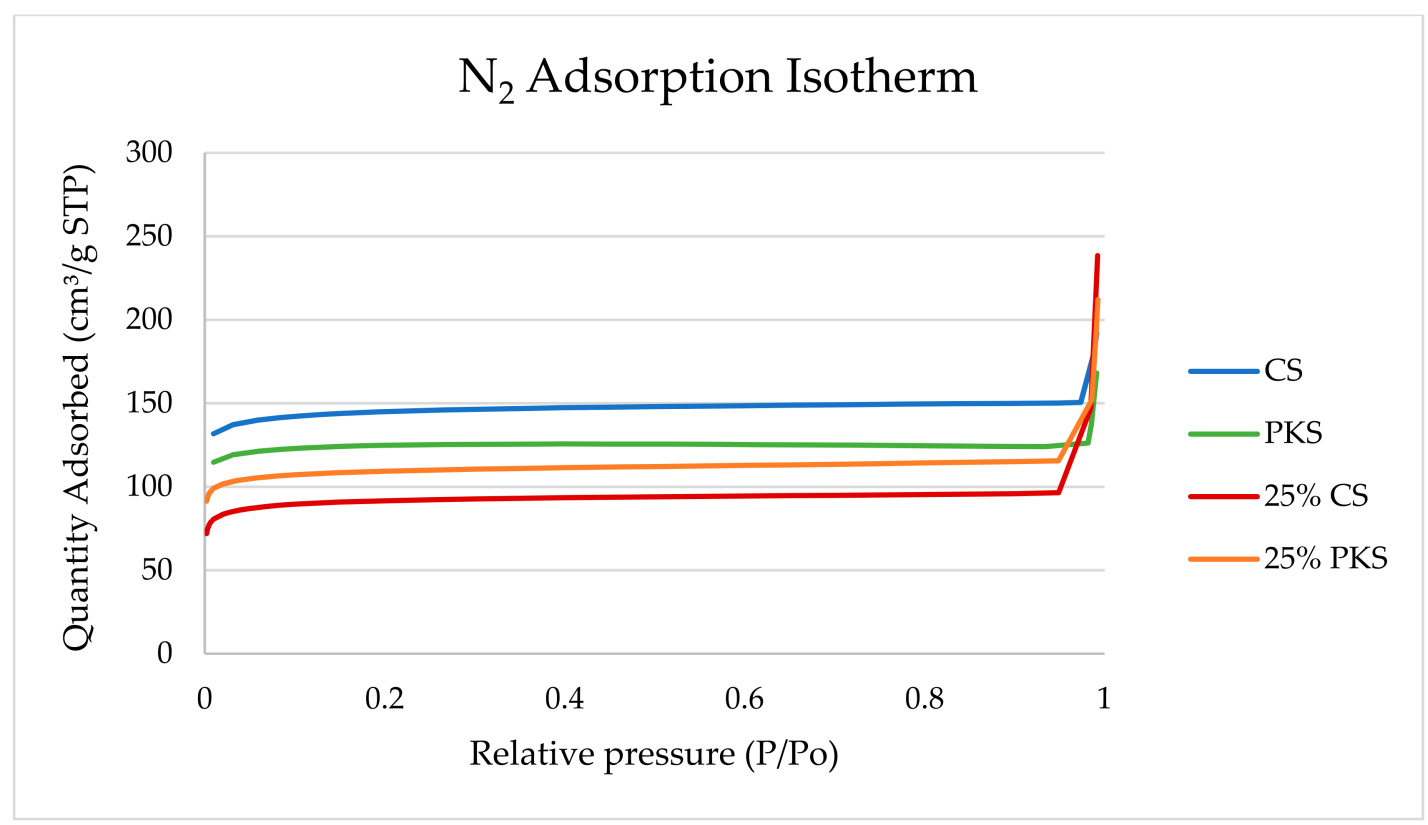

Figure 3. $\mathrm{N}_{2}$ adsorption isotherm for activated carbon prepared at $700{ }^{\circ} \mathrm{C}$ for $75 \mathrm{~min}$ (reference sample) and activated carbon $\left(700{ }^{\circ} \mathrm{C}, 75 \mathrm{~min}\right)$ post-treated with $25 \% \mathrm{NaOH}$.

\subsection{Surface Morphology of Activated Carbon}

Scanning electron micrography was performed on the reference samples (activated carbon without surface modification) and activated carbon with $\mathrm{NaOH}$ surface modification, which obtained the highest adsorption properties. This includes the reference samples (activated carbon prepared at $700{ }^{\circ} \mathrm{C}$ for $75 \mathrm{~min}$ ) and the activated carbon $\left(700{ }^{\circ} \mathrm{C}, 75 \mathrm{~min}\right)$ post-treated with $25 \% \mathrm{NaOH}$.

This experiment further manifests the capability of $\mathrm{NaOH}$ surface modification to penetrate deeper into the structure of activated carbon, creating cavities and pores, thus increasing the surface area. The morphology analysis revealed that the reference samples have a poor pore structure. Figure $4 \mathrm{a}, \mathrm{b}$ show that the reference samples almost have no microporous structure when compared to the activated carbon with $\mathrm{NaOH}$ surface modification. The pores of the CS reference samples were mostly closed, and the pores for the PKS reference samples were not visible during the SEM magnification, while surface modification with $\mathrm{NaOH}$ produced rugged surfaces with microporous properties on both types of nutshell-derived activated carbons, indicating that the porous structure is well developed. The surface modification technique used in this study mainly alters the pore structure of activated carbon, such as specific surface area, pore volume, and pore size. Furthermore, unclogged cavities were observed on the surfaces of both the activated carbon samples with $\mathrm{NaOH}$ surface modification (refer to Figure $4 \mathrm{c}$,d). This clearly indicates that under the same carbonization temperature, the formation of microporous structures on the activated carbon were mainly contributed to by the additional $\mathrm{NaOH}$ surface modification stage. The surface morphology and surface characteristic analysis were used to explain the activated carbon's high adsorption performance. Overall, a surface-activated carbon (surface modification with $25 \% \mathrm{NaOH}$ ) with excellent adsorption performance on iodine and methylene blue was obtained in this study. 


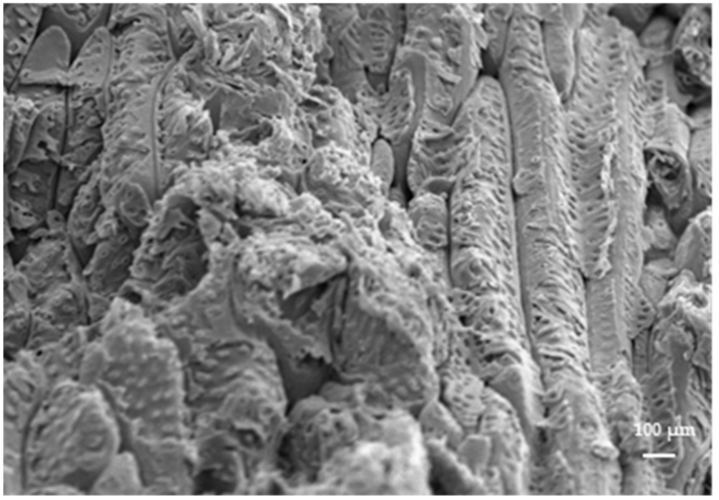

(a) CS reference sample

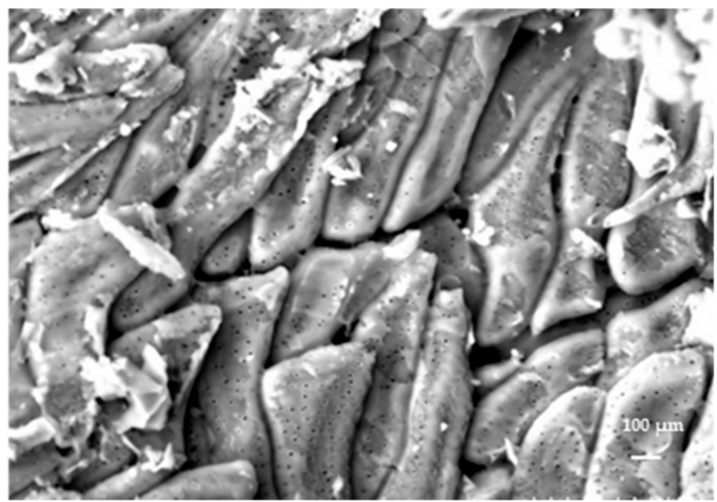

(c) CS post-treated activated carbon

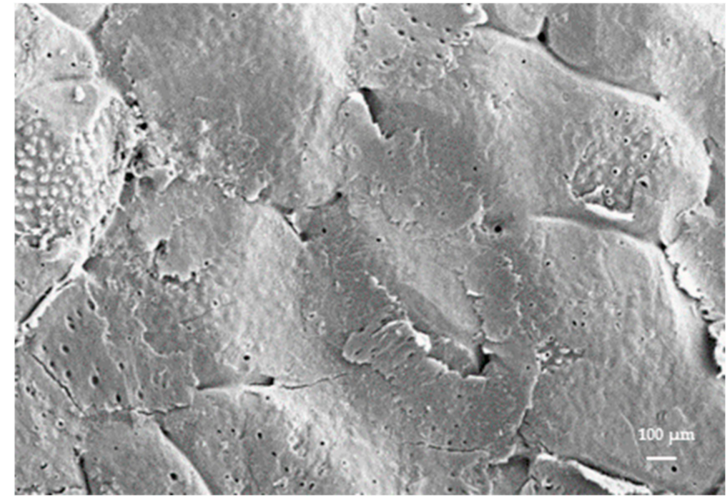

(b) PKS reference sample

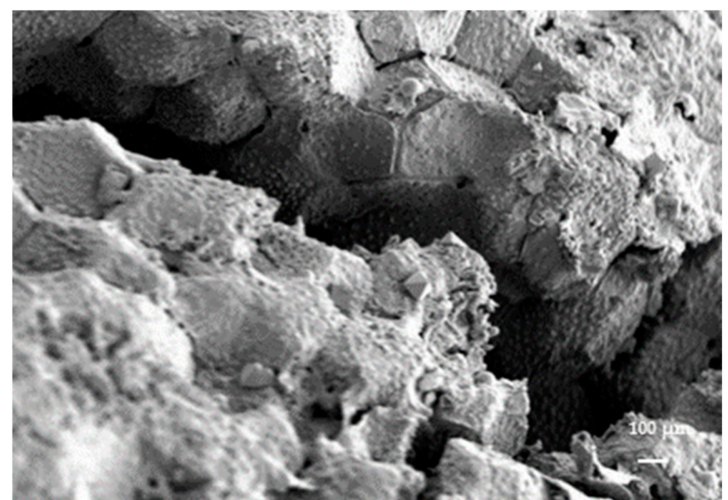

(d) PKS post-treated activated carbon

Figure 4. Scanning electron micrographs of $(\mathbf{a}, \mathbf{b})$ activated carbon prepared at $700{ }^{\circ} \mathrm{C}$ for 75 min and (c,d) activated carbon $\left(700{ }^{\circ} \mathrm{C}, 75 \mathrm{~min}\right.$ ) post-treated with $25 \% \mathrm{NaOH}$ at $1000 \times$ magnification.

\subsection{Surface Chemical Characteristics of Activated Carbon}

Evaluations of the surface chemical characteristics in this study were only performed on the activated carbon that obtained the highest adsorption properties and the highest surface area. This includes the reference samples (activated carbon prepared at $700{ }^{\circ} \mathrm{C}$ for $75 \mathrm{~min}$ ) and activated carbon $\left(700{ }^{\circ} \mathrm{C}, 75 \mathrm{~min}\right)$ post-treated with $25 \% \mathrm{NaOH}$.

FTIR techniques were used to examine the functional and surface chemistry of the prepared activated carbon samples. As illustrated in Figure 5, activated carbon prepared without surface modification exhibits its characteristic peaks at $3438 \mathrm{~cm}^{-1}$, which are assigned to the hydroxyl (O-H). The strong peaks at $3455 \mathrm{~cm}^{-1}$ for activated carbon modified with $25 \% \mathrm{NaOH}$ can be attributed to O-H stretching. The peak shift from $3438 \mathrm{~cm}^{-1}$ to $3455 \mathrm{~cm}^{-1}$ indicates that as a reducing agent, $\mathrm{NaOH}$ prevents hydrogen bonding and removes the $\mathrm{OH}$ functional groups on activated carbon [30]. Furthermore, the peaks corresponding to the $\mathrm{O}-\mathrm{H}$ groups and the aliphite groups became weaker or disappeared with surface modification. Hence, the broad $\mathrm{O}-\mathrm{H}$ peak was replaced by a sharp signal at $3455 \mathrm{~cm}^{-1}$. Carboxylic functional groups were observed in $2337 \mathrm{~cm}^{-1}[31,32]$ for the PKS-activated carbon modified with $25 \% \mathrm{NaOH}$. Moreover, the peaks at $3740 \mathrm{~cm}^{-1}$ and $3400 \mathrm{~cm}^{-1}$ corresponding to the $-\mathrm{NH}_{2}$ stretching and $-\mathrm{OH}$ stretching of hydroxyl groups [33] were observed in both of the $\mathrm{NaOH}$ surface modified samples. CS-activated carbon modified with $\mathrm{NaOH}$ caused the appearance of several new absorption peaks. These peaks can be classified as follows: $\mathrm{C} \equiv \mathrm{C}$ group $\left(2348 \mathrm{~cm}^{-1}\right)$ [33] and $\mathrm{C}-\mathrm{N}$ stretching vibration absorption peaks $\left(1221 \mathrm{~cm}^{-1}\right)$ [34]. Alternative polymerization conditions occurred with $\mathrm{NaOH}$ surface modification, which serves as a useful control to demonstrate the importance of surface area for rapid micropollutant removal [35]. The surface modification of activated carbon improves chemical adsorption by increasing the active 
functional groups on the surface [36]. This concludes that surface modification with $\mathrm{NaOH}$ greatly increases the functional group of activated carbon and thereby directly increases the adsorption capability of activated carbon.

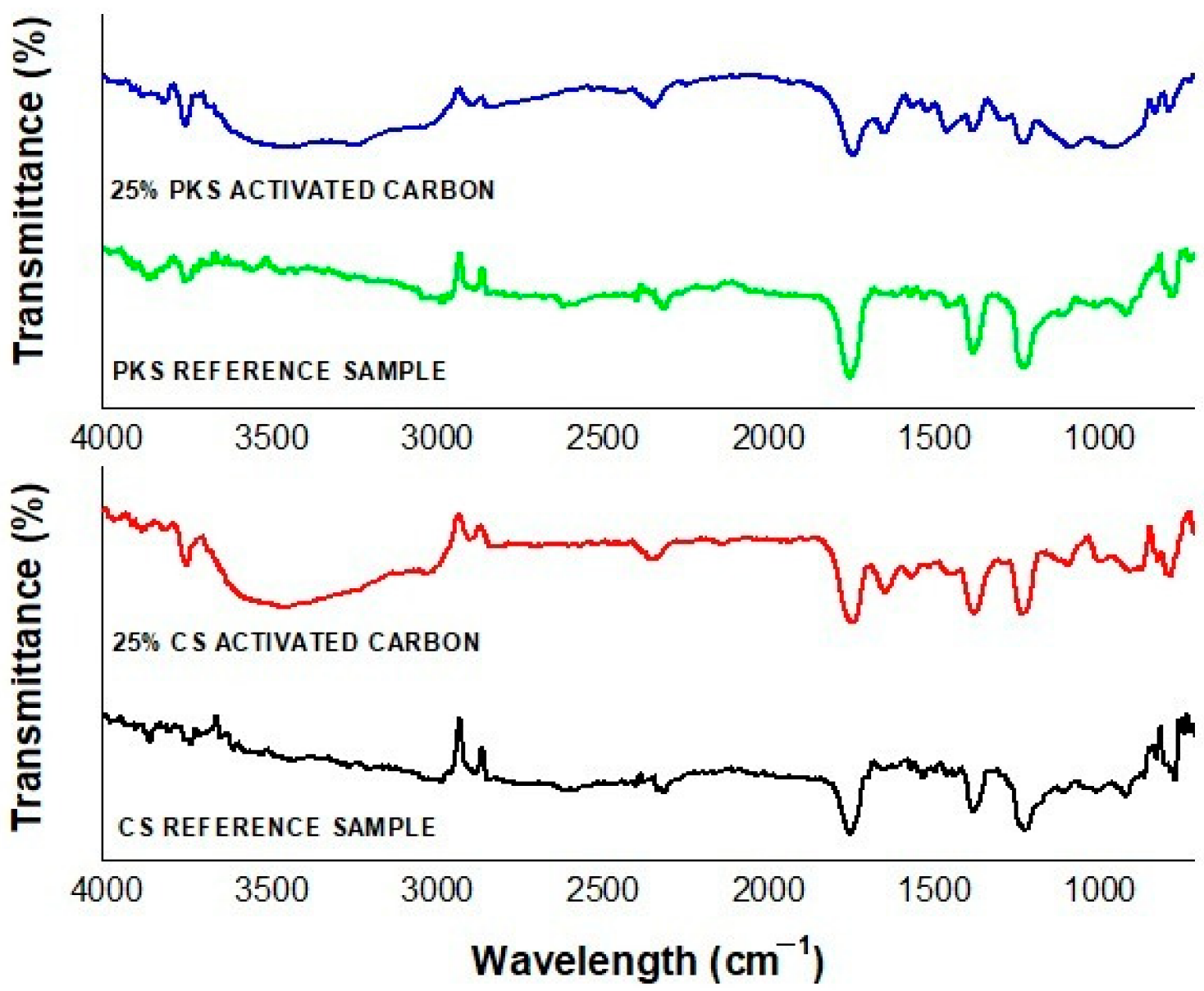

Figure 5. FTIR for CS and PKS activated carbons prepared in $700{ }^{\circ} \mathrm{C}$ for $75 \mathrm{~min}$ (reference sample) and activated carbon $\left(700{ }^{\circ} \mathrm{C}, 75 \mathrm{~min}\right.$ ) post-treated with $25 \%$ of $\mathrm{NaOH}$.

\subsection{Correlation of Surface Area and Micropore}

In order to achieve the greatest possible activated carbon production from biomass, a precise understanding of the relationship between the surface structure and the pore assessment is required. Surface area and pore size are widely used parameters for activated carbon testing due to their simplicity and the availability of a rapid assessment for sample simplicity and a rapid assessment of the absorbent quality of the samples in question. The correlation results of the surface area and micropore surface area of the prepared activated carbon is given in Table 4, while Figure 6 presents the reference samples prepared at $700{ }^{\circ} \mathrm{C}$ for $75 \mathrm{~min}$ and activated carbon $\left(700{ }^{\circ} \mathrm{C}, 75 \mathrm{~min}\right)$ post-treated with $25 \% \mathrm{NaOH}$ at low magnification. Lower magnifications, which represent wider fields of view, allow for a broad range of pore sizes to be observed, though only larger pores can be identified. When the magnification is increased to a certain level, the field of view narrows and only a portion of the micropores is visible [37]. Thus, the different pore size distribution characteristics under different magnifications (Figure 4: 1000×; Figure 6: 2000×) demonstrate the importance of magnification in image analyses for the activated carbon. 
Table 4. Correlation of surface area and micropore of the prepared activated carbons.

\begin{tabular}{|c|c|c|c|}
\hline \multicolumn{2}{|c|}{ Correlation } & \multirow{3}{*}{$\begin{array}{c}\text { Micropore Surface Area } \\
1\end{array}$} & \multirow{2}{*}{$\begin{array}{c}\text { Total Surface Area } \\
0.858^{* *}\end{array}$} \\
\hline & Pearson Correlation & & \\
\hline Micropore surface area & Sig. (2-tailed) & & 0.000 \\
\hline & $\mathrm{N}$ & 18 & 18 \\
\hline \multirow{3}{*}{ Total surface area } & Pearson Correlation & $0.858^{* *}$ & 1 \\
\hline & Sig. (2-tailed) & 0.000 & \\
\hline & $\mathrm{N}$ & 18 & 18 \\
\hline
\end{tabular}

** Correlation is significant at the 0.01 level (2-tailed).

Carbon pores have a wide range of sizes (widths) from $0.1 \mathrm{~nm}$ to more than $10 \mathrm{~mm}$, which can be classified as micropores (less than $2 \mathrm{~nm}$ in size), mesopores (2-50 nm), and macropores (more than $50 \mathrm{~nm}$ ). Micropores are further divided into ultramicropores (less than $0.7 \mathrm{~nm}$ in size) and supermicropores $(0.7-2 \mathrm{~nm})$ [38,39]. In this work, we tried to establish a correlation between the BET surface area and the microporosity of the activated carbon. The Pearson correlation coefficient is a measure of the linear relationship between two variables and is the most frequently used measure of association between variables [40]. The results (Table 4) show the strong significant correlation between the micropores on the specific surface area of the activated carbon derived from PKS and CS. In principle, the higher the proportion of microporosity, the greater the specific surface area. The growth at the specific surface area of activated carbon achieved with the presence of high a proportion of microporosity is also demonstrated in Figure 6.

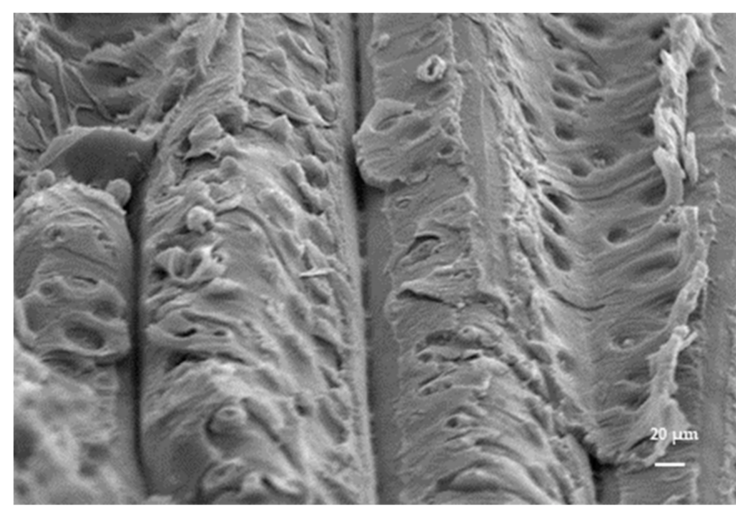

(a) CS reference sample

Bet surface area: $204.6404 \mathrm{~m}^{2} \mathrm{~g}^{-1}$

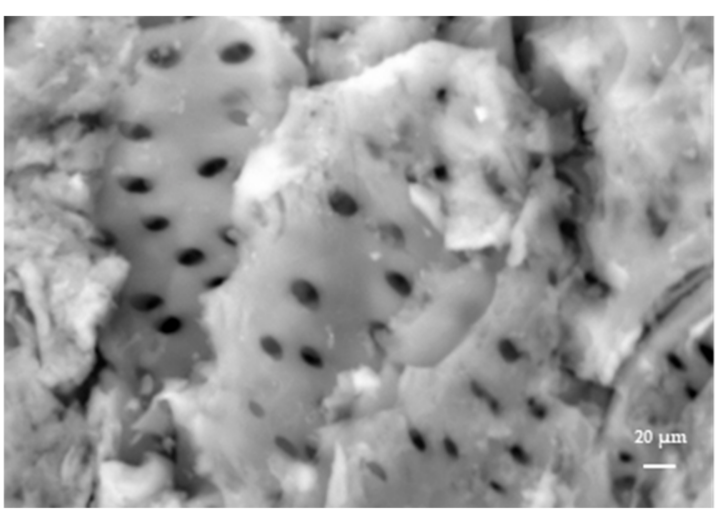

(c) CS post-treated activated carbon Bet surface area: $356.8685 \mathrm{~m}^{2} \mathrm{~g}^{-1}$

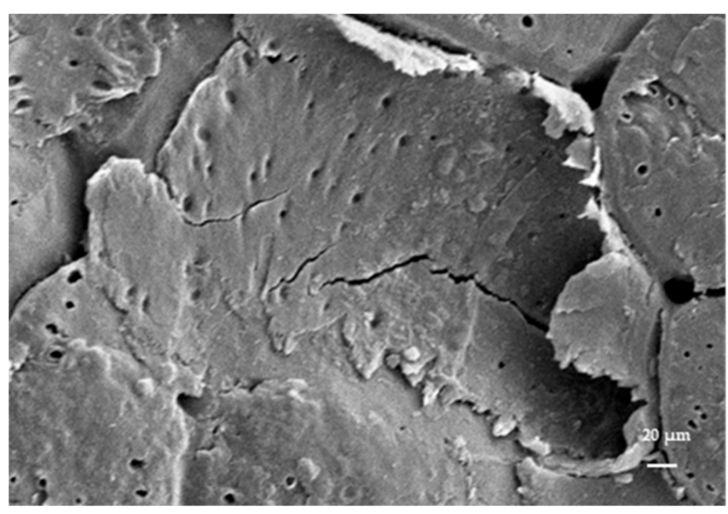

(b) PKS reference sample

Bet surface area: $135.9660 \mathrm{~m}^{2} \mathrm{~g}^{-1}$

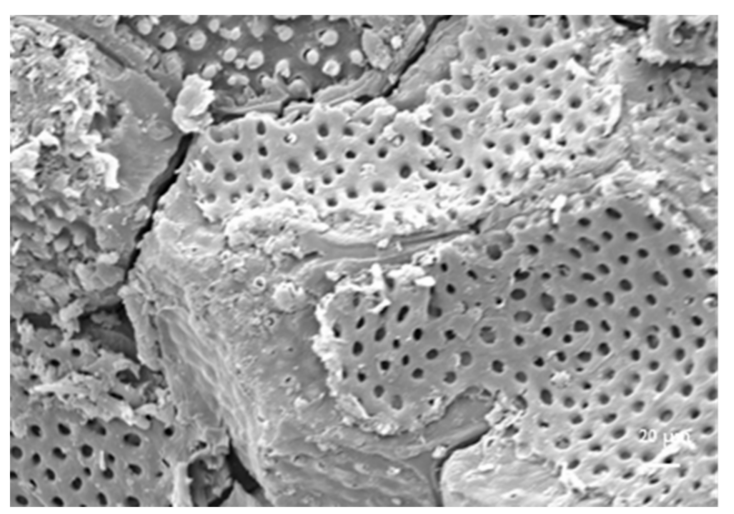

(d) PKS post-treated activated carbon Bet surface area: $427.6408 \mathrm{~m}^{2} \mathrm{~g}^{-1}$

Figure 6. Scanning electron micrographs of $(\mathbf{a}, \mathbf{b})$ activated carbons prepared at $700{ }^{\circ} \mathrm{C}$ for 75 min and (c,d) activated carbon $\left(700{ }^{\circ} \mathrm{C}, 75 \mathrm{~min}\right.$ ) post-treated with $25 \% \mathrm{NaOH}$ at $2000 \times$ magnification. 
Low magnification was applied in order to obtain the apparent pore structure on the surface of the activated carbon samples. Figure $6 \mathrm{a}, \mathrm{b}$ shows that the surface structure of the reference sample was primitively rough with no visible pores. The SEM analysis suggested that $\mathrm{NaOH}$ surface modification was effective to fabricate activated carbon with a higher specific surface area and narrower size distribution. The SEM results (Figure $6 c, d$ ) show the presence of micropores in both samples prepared via $\mathrm{NaOH}$ surface modification, with the quantity of the pores being slightly increased with the decrease of the pore size. The PKS-activated carbon post-treated with $\mathrm{NaOH}$ (Figure $6 \mathrm{~d}$ ) reveals a large proportion of supermicropores, i.e., voids of widths less than $2 \mathrm{~nm}$, while the untreated activated carbons (Figure $6 \mathrm{a}, \mathrm{b}$ ) possessed a bigger pore size and a larger proportion of mesopores. Principally, the specific surface area of activated carbon seems to be highly relevant with the proportion of microporosity. The results of the present study demonstrate that highly microporous activated carbon with a high surface area can be prepared from CS and PKS prepared with $\mathrm{NaOH}$ surface modification. Through the surface area characteristic and surface morphology results, micropores were found to be one of the most important elements in the preparation of a high grade activated carbon.

\section{Conclusions}

In this study, $\mathrm{NaOH}$ surface modification was introduced to fabricate microporous structure activated carbons. The results show that after surface modification, activated carbon has high surface and pore volume values, indicating that $\mathrm{NaOH}$ treatment is effective in improving the performance of nutshell-derived activated carbons. The entire $80 \%$ of the total pore ratio was occupied with micropores for both types of nutshell-derived activated carbons prepared via $\mathrm{NaOH}$ surface modification. This unique method is capable of creating new micropores on activated carbon. Surface modifications also improve adsorption capacity by increasing the active functional groups on the surface of carbon. The findings also show that using high carbonization temperatures accelerates the $\mathrm{NaOH}$ surface modification process. The highest adsorption capacity was achieved by $\mathrm{NaOH}-$ surface modified samples from activated carbon prepared at $700{ }^{\circ} \mathrm{C}$. Furthermore, this study also discloses that a direct correlation between the proportion of micropores and the specific surface area is evident. A higher proportion of micropores in the carbon particles is associated with a higher specific surface area. By applying the $\mathrm{NaOH}$ post-treatment as the ultimate surface modification technique to the activated carbon derived from PKS and CS, a highly microporous structure was produced.

Author Contributions: Conceptualization, M.S.H.; validation, P.S.K.; writing-original draft preparation, C.L.L. and M.S.H.; writing-review and editing, K.L.C.; supervision, P.S.H. and U.R.; project administration, P.S.H.; funding acquisition, P.S.H. All authors have read and agreed to the published version of the manuscript.

Funding: The authors are grateful for the financial support given by the Ministry of Higher Education Malaysia (MOHE) under the Higher Institution Centre of Excellence (HICoE) project at the Institute of Tropical Forestry and Forest Products, which was given by the Ministry of Higher Education, Malaysia (MOHE). This research was also supported by Fundamental Research Grant Scheme (FRGS) from the Ministry of Higher Education (MOHE), Malaysia, under the grant FRGS/1/2019/WAB07/UPM/02/2.

Institutional Review Board Statement: Not applicable.

Informed Consent Statement: Not applicable.

Data Availability Statement: All relevant data are within the manuscript.

Acknowledgments: The authors also sincerely thank the postgraduate students that participated in this research.

Conflicts of Interest: The authors declare no conflict of interest. 


\section{References}

1. Goi, C.L. The river water quality before and during the Movement Control Order (MCO) in Malaysia. Case Stud. Chem. Environ. Eng. 2020, 2, 100027. [CrossRef]

2. Najah, A.; Teo, F.Y.; Chow, M.F.; Huang, Y.F.; Latif, S.D.; Abdullah, S.; Ismail, M.; El-Shafie, A. Surface water quality status and prediction during movement control operation order under COVID-19 pandemic: Case studies in Malaysia. Int. J. Environ. Sci. Technol. 2021, 18, 1009-1018. [CrossRef]

3. Jasim, N.A. The design for wastewater treatment plant (WWTP) with GPS X modelling. Cogent Eng. 2020, 7, 1723782. [CrossRef]

4. Musa, M.; Idrus, S. Physical and Biological Treatment Technologies of Slaughterhouse Wastewater: A Review. Sustainability 2021, 13, 4656. [CrossRef]

5. Dash, R.R.; Mohanty, S. Removal of organic matters and nutrients by using bio-balls and corn cobs as bio-film carrier in MBBR technology. In Water Security and Sustainability; Springer: Singapore, 2021; pp. 227-237.

6. Fröhlich, A.C.; Foletto, E.L.; Dotto, G.L. Preparation and characterization of NiFe2O4/activated carbon composite as potential magnetic adsorbent for removal of ibuprofen and ketoprofen pharmaceuticals from aqueous solutions. J. Clean. Prod. 2019, 229, 828-837. [CrossRef]

7. Saad, M.J.; Chia, C.; Zakaria, S.; Sajab, M.S.; Misran, S. Malaysia rice wastes for activated carbon production. In Proceedings of the 9th Kuala Lumpur International Agriculture, Forestry and Plantation Conference, Bangi, Malaysia, 21-22 September 2020; pp. 20-26.

8. Bhatnagar, A. (Ed.) Application of Adsorbents for Water Pollution Control; Bentham Science Publishers: Sharjah, United Arab Emirates, 2012.

9. Mahanim, S.M.A.; Asma, I.W.; Rafidah, J.; Puad, E.; Shaharuddin, H. Production of activated carbon from industrial bamboo wastes. J. Trop. For. Sci. 2011, 23, 417-424.

10. Anwar, Z.; Gulfraz, M.; Irshad, M. Agro-industrial lignocellulosic biomass a key to unlock the future bio-energy: A brief review. J. Radiat. Res. Appl. Sci. 2014, 7, 163-173. [CrossRef]

11. Lee, C.L.; H’Ng, P.S.; Paridah, T.; Chin, K.L.; Rashid, U.; Maminski, M.; Go, W.Z.; Nazrin, R.A.R.; Rosli, S.N.A.; Khoo, P.S. Production of bioadsorbent from phosphoric acid pretreated palm kernel shell and coconut shell by two-stage continuous physical activation via $\mathrm{N}_{2}$ and air. R. Soc. Open Sci. 2018, 5, 180775. [CrossRef] [PubMed]

12. Bădescu, I.S.; Bulgariu, D.; Ahmad, I.; Bulgariu, L. Valorisation possibilities of exhausted biosorbents loaded with metal ions-A review. J. Environ. Manag. 2018, 224, 288-297. [CrossRef]

13. Manyangadze, M.; Chikuruwo, N.; Narsaiah, T.; Chakra, C.; Radhakumari, M.; Danha, G. Enhancing adsorption capacity of nano-adsorbents via surface modification: A review. S. Afr. J. Chem. Eng. 2020, 31, 25-32. [CrossRef]

14. Ambaye, T.G.; Vaccari, M.; van Hullebusch, E.D.; Amrane, A.; Rtimi, S. Mechanisms and adsorption capacities of biochar for the removal of organic and inorganic pollutants from industrial wastewater. Int. J. Environ. Sci. Technol. 2021, 18, 3273-3294. [CrossRef]

15. Chin, K.L.; Lee, C.L.; H'ng, P.S.; Rashid, U.; Paridah, M.T.; Khoo, P.S.; Maminski, M. Refining micropore capacity of activated carbon derived from coconut shell via deashing post-treatment. Bioresource 2020, 15, 7749-7769. [CrossRef]

16. Zhang, Y.; Song, X.; Xu, Y.; Shen, H.; Kong, X.; Xu, H. Utilization of wheat bran for producing activated carbon with high specific surface area via $\mathrm{NaOH}$ activation using industrial furnace. J. Clean. Prod. 2019, 210, 366-375. [CrossRef]

17. Xu, B.; Chen, Y.; Wei, G.; Cao, G.; Zhang, H.; Yang, Y. Activated carbon with high capacitance prepared by $\mathrm{NaOH}$ activation for supercapacitors. Mater. Chem. Phys. 2010, 124, 504-509. [CrossRef]

18. Lee, C.L.; H'ng, P.S.; Paridah, M.T.; Chin, K.L.; Khoo, P.S.; Nazrin, R.A.R.; Asyikin, S.N.; Mariusz, M. Effect of reaction time and temperature on the properties of carbon black made from palm kernel and coconut shell. Asian J. Sci. Res. 2017, 10, 24-33. [CrossRef]

19. Liew, R.K.; Azwar, E.; Yek, P.N.Y.; Lim, X.Y.; Cheng, C.K.; Ng, J.-H.; Jusoh, A.; Lam, W.-H.; Ibrahim, M.D.; Ma, N.L.; et al. Microwave pyrolysis with $\mathrm{KOH} / \mathrm{NaOH}$ mixture activation: A new approach to produce micro-mesoporous activated carbon for textile dye adsorption. Bioresour. Technol. 2018, 266, 1-10. [CrossRef]

20. Liu, Z.; Niu, W.; Chu, H.; Zhou, T.; Niu, Z. Effect of the Carbonization Temperature on the Properties of Biochar Produced from the Pyrolysis of Crop Residues. Bioresource 2018, 13, 3429-3446. [CrossRef]

21. Cao, J.; Xiao, G.; Xu, X.; Shen, D.; Jin, B. Study on carbonization of lignin by TG-FTIR and high-temperature carbonization reactor. Fuel Process. Technol. 2013, 106, 41-47. [CrossRef]

22. Cazetta, A.L.; Vargas, A.; Nogami, E.M.; Kunita, M.H.; Guilherme, M.R.; Martins, A.C.; Silva, T.L.; Moraes, J.C.; Almeida, V.C. $\mathrm{NaOH}$-activated carbon of high surface area produced from coconut shell: Kinetics and equilibrium studies from the methylene blue adsorption. Chem. Eng. J. 2011, 174, 117-125. [CrossRef]

23. Kumar, R.H.S.M. Removal of Ash from Indian Assam Coking Coal Using Sodium Hydroxide and Acid Solutions. Energy Sources 2000, 22, 187-196. [CrossRef]

24. Emara, M.M.; Farag, R.S.; Mubarak, M.F.; Ali, S.K. Synthesis of core-shell activated carbon/CaO composite from Ficus Nitida leaves, as an efficient adsorbent for removal of methylene blue. Nanotechnol. Environ. Eng. 2020, 5, 1-14. [CrossRef]

25. Lee, C.L.; H'Ng, P.S.; Chin, K.L.; Paridah, T.; Rashid, U.; Go, W.Z. Characterization of bioadsorbent produced using incorporated treatment of chemical and carbonization procedures. R. Soc. Open Sci. 2019, 6, 190667. [CrossRef] [PubMed] 
26. Mojoudi, N.; Mirghaffari, N.; Soleimani, M.; Shariatmadari, H.; Belver, C.; Bedia, J. Phenol adsorption on high microporous activated carbons prepared from oily sludge: Equilibrium, kinetic and thermodynamic studies. Sci. Rep. 2019, 9, 1-12. [CrossRef]

27. Saad, M.J.; Chia, C.H.; Misran, S.; Zakaria, S.; Sajab, M.S.; Rahman, M.H.A. Rice Husk Activated Carbon with NaOH Activation: Physical and Chemical Properties. Sains Malays. 2020, 49, 2261-2267. [CrossRef]

28. Shi, J.; Lu, Y.; Zhang, Y.; Cai, L.; Shi, S.Q. Effect of thermal treatment with water, $\mathrm{H} 2 \mathrm{SO} 4$ and NaOH aqueous solution on color, cell wall and chemical structure of poplar wood. Sci. Rep. 2018, 8, 17735. [CrossRef]

29. Heidarinejad, Z.; Dehghani, M.H.; Heidari, M.; Javedan, G.; Ali, D.I.; Sillanpää, M. Methods for preparation and activation of activated carbon: A review. Environ. Chem. Lett. 2020, 18, 393-415. [CrossRef]

30. Owais, M.; Zhao, J.; Imani, A.; Wang, G.; Zhang, H.; Zhang, Z. Synergetic effect of hybrid fillers of boron nitride, graphene nanoplatelets, and short carbon fibers for enhanced thermal conductivity and electrical resistivity of epoxy nanocomposites. Compos. Part A Appl. Sci. Manuf. 2019, 117, 11-22. [CrossRef]

31. Syabaniah, N.F.; Syarif, N.; Rohendi, D.; Wandasari, M.; Rengga, W.D. The Light Transmittance and Electrical Conductivity Properties of Gelam Wood Carbon Nanosheet and Its Derivatives. Indones. J. Fundam. Appl. Chem. 2019, 4, 126-131. [CrossRef]

32. Syabania, N.F.; Sudarsono, W.; Rohendi, D.; Syarif, N. Functionality Analysis of Carbon Nanosheet, Oxidized Carbon Nanosheet and Reduced Carbon Nanosheet Oxide by Using Fourier Transform Infra Red and Boehm Titration Method. J. Phys. Conf. Ser. 2018, 1095, 012028. [CrossRef]

33. Derdour, K.; Bouchelta, C.; Naser-Eddine, A.K.; Medjram, M.S.; Magri, P. Removal of Cr(VI) from aqueous solutions by using activated carbon supported iron catalysts as efficient adsorbents. World J. Eng. 2018, 15, 3-13. [CrossRef]

34. Ren, Q.; Shen, X.; Zhang, J.; Liu, J. Simultaneous Reduction and Covalent Combining of Tetraethylenepentamine on Graphene Oxide. IOP Conf. Ser. Mater. Sci. Eng. 2019, 472, 012096. [CrossRef]

35. Alsbaiee, A.; Smith, B.J.; Xiao, L.; Ling, Y.; Helbling, D.E.; Dichtel, W. Rapid removal of organic micropollutants from water by a porous $\beta$-cyclodextrin polymer. Nat. Cell Biol. 2016, 529, 190-194. [CrossRef] [PubMed]

36. Wang, T.; Liu, J.; Zhang, Y.; Zhang, H.; Chen, W.-Y.; Norris, P.; Pan, W.-P. Use of a non-thermal plasma technique to increase the number of chlorine active sites on biochar for improved mercury removal. Chem. Eng. J. 2018, 331, 536-544. [CrossRef]

37. Jin, W.; Xu, W.; Liang, H.; Li, Y.; Liu, S.; Li, B. Nanoemulsions for Food: Properties, Production, Characterization, and Applications; Elsevier BV: Amsterdam, The Netherlands, 2016; pp. 1-36.

38. Kerr, R.; Garvin, J.; Heaton, N.; Boyle, E. Emotional intelligence and leadership effectiveness. Leadersh. Organ. Dev. J. 2006, 27, 265-279. [CrossRef]

39. Nishi, Y.; Inagaki, M. Gas Adsorption/Desorption Isotherm for Pore Structure Characterization. Mater. Sci. Eng. Carbon 2016, 11, 227-247. [CrossRef]

40. Gottipati, R. Preparation and Characterization of Microporous Activated Carbon from Biomass and Its Application in the Removal of Chromium (Vi) from Aqueous Phase; National Institute of Technology: Rourkela, India, 2012. 